\title{
Pioglitazone Hydrochloride
}

National Cancer Institute

\section{Source}

National Cancer Institute. Pioglitazone Hydrochloride. NCI Thesaurus. Code C29367.

The hydrochloride salt of an orally-active thiazolidinedione with antidiabetic properties and potential antineoplastic activity. Pioglitazone activates peroxisome proliferatoractivated receptor gamma (PPAR-gamma), a ligand-activated transcription factor, thereby inducing cell differentiation and inhibiting cell growth and angiogenesis. This agent also modulates the transcription of insulin-responsive genes, inhibits macrophage and monocyte activation, and stimulates adipocyte differentiation. ( $\mathrm{NCl05)}$ 